\title{
Omohyoid Muscle
}

National Cancer Institute

\section{Source}

National Cancer Institute. Omohyoid Muscle. NCI Thesaurus. Code C52971.

A skeletal muscle belonging to the infrahydoid muscle group, located in the anterior part of the neck with its orig in on the upper border of the scapula and insertion on the hyoid bone; it functions to depress the hyoid bone. 